\title{
Geochemical Characterization of Two Niger Delta Crude Oils and Their Mixtures I: Bulk Properties and Aliphatic Hydrocarbon Distributions
}

\author{
Mark O. Onyema, Nwannedi C. Okoroh, Ikenna H. Okorie, Leo C. Osuji \\ Department of Pure and Industrial Chemistry, University of Port Harcourt, Port Harcourt, Nigeria
}

\section{Email address:}

onyemark@yahoo.com (M. O. Onyema)

\section{To cite this article:}

Mark O. Onyema, Nwannedi C. Okoroh, Ikenna H. Okorie, Leo C. Osuji. Geochemical Characterization of Two Niger Delta Crude Oils and Their Mixtures I: Bulk Properties and Aliphatic Hydrocarbon Distributions. Modern Chemistry. Vol. 6, No. 3, 2018, pp. 39-43.

doi: $10.11648 /$ j.mc.20180603.11

Received: August 26, 2018; Accepted: September 18, 2018; Published: December 20, 2018

\begin{abstract}
Two crude oils from Rivers and Delta States, Niger Delta Nigeria, samples A and F respectively, and their binary mixtures at different compositions, samples B, C, D, and E, were geochemically characterized using bulk properties and aliphatic hydrocarbon distributions. Results of density and API gravity, which classified samples A, B, C, D as light oils and samples E, F as medium oils, were observed to increase and decrease with increase in the composition of oil sample $\mathrm{F}$ respectively. The composition of the saturates, from 68.00 to $71.10 \%$, suggest high maturity of the oil samples which did not show a relationship to the compositional mix of the two Niger Delta crude oils. Bimodal distribution of $n$-alkanes in samples A and B with a slight prominence of the short chain suggest marine source with significant terrestrial input, while the prominence of the long chain $n$ alkanes in sample $\mathrm{F}$, which suggest a terrestrial source, progressively increased in samples $\mathrm{C}, \mathrm{D}$, and $\mathrm{E}$. $\mathrm{Pr} / \mathrm{Ph}$ ratios from 2.37 to 2.70 suggest source rocks deposited in an oxic environment. Ratios of $\operatorname{Pr} / n \mathrm{C}_{17}$, from 0.94 to 1.20 , and $\mathrm{Ph} / n \mathrm{C}_{18}$, from 0.39 to 0.53 , suggest shale source rocks with terrestrial higher plant input. From these results, the geochemical characteristics of the individual Niger Delta crude oils were exhibited by their binary mixtures. However, density, API gravity, n-alkane distribution, $\operatorname{Pr} / n \mathrm{C}_{17}$ and $\mathrm{Ph} / n \mathrm{C}_{18}$ ratios were expressed relative to the compositional mix of the two Niger Delta crude oils.
\end{abstract}

Keywords: N-alkane, Composition, Isoprenoid, Crude Oil Mixture, Diagnostic Ratio

\section{Introduction}

Correlation studies of crude oils require parameters that discriminate a homologous suit of oils (oils from the same source) from another [1]. This is primarily accomplished using bulk properties such as American petroleum institute (API) gravity, compound class fractions - saturates, aromatics, resins and asphaltenes (SARA) and distribution of aliphatic hydrocarbons (AHCs) from C8 to C40 normal alkanes (nalkanes) including the isoprenoids pristane and phytane $[2,3$, 4]. Additional data from biological marker (biomarker) and alkylated polycyclic aromatic hydrocarbon analysis are used to support these parameters $[5,6,7]$. The qualitative and quantitative comparisons of these parameters are important to geochemists for establishing relationship between crude oils [8].

Crude oils are usually characterized by their API gravity range as heavy $\left(<25^{\circ} \mathrm{API}\right)$, medium $\left(25^{\circ}-35^{\circ}\right)$, light $\left(35^{\circ}\right.$ - $45^{\circ}$ ) and condensates $\left(>45^{\circ}\right)$. Data about the composition of the SARA fraction of crude oils is valuable for oil correlation as well as refining processes. The stability of asphaltenes in organic deposition during petroleum production, processing, and refining is related to the SARA composition of crude oil and cannot be associated with only one fraction [9]. Nwadinigwe et al. (2017) showed that despite API gravities of three Nigerian Niger Delta crude oils, Kokori $34.19^{\circ}$, Afiesere $37.76^{\circ}$ and Nembe $39.39^{\circ}$, indicated light oils, the aromatics/saturate ratios ascertained Kokori with the lowest ratio of 0.092 will cause more problem by asphaltene deposition in the refinery than the other oils [10].

Aliphatic hydrocarbon distribution and composition (fingerprint) of crude oils vary for different sources [11]. nalkane fingerprints obtained from gas chromatography (GC) analysis and characterized by the prominence of $\mathrm{nC} 13$ to $\mathrm{nC} 19$ reflect marine organic sources such as algae, plankton, and bacteria, while the prominence of the $\mathrm{nC} 25$ to $\mathrm{nC} 35$ are usually 
associated with terrestrial higher plant waxes [12]. The relative abundance of pristane and phytane also provide valuable information on source organic matter input, redox potential of the organic matter depositional environment, lithology of the source rock, maturation and biodegradation [13, 14]. In the characterization of crude oil mixtures, Oyekunle and Famakin (2004) noticed that oils characterized by the same specific gravity do not necessarily exhibit the same viscosity. They showed that only binary mixtures of light crude oils produced linear viscosity - compositional relationship [15]. Thus, this study is aimed at assessing the relationship between the geochemical characteristics of two crude oils from different areas of Nigeria's Niger Delta and their binary mixtures.

\section{Materials and Methods}

\subsection{Study Area}

The Niger Delta region is situated in Southern Nigeria between longitude $5^{\circ}-9^{\circ} \mathrm{E}$ and latitude $4^{\circ}-6^{\circ} \mathrm{N}$ on the West African continental margin and at the apex of the Gulf of Guinea [16]. The region is an extremely prolific hydrocarbon province with three stratigraphic sequences namely: the marine shale Akata formation, the shale interbedded with paralic sandstone of the Agbada formation and the Benin formation, which consist of coastal plain sands [17]. Nigeria's Niger Delta region consists of nine (9) states namely: Ondo, Edo, Delta, Imo, Abia, Bayelsa, Rivers, Akwa-Ibom and Cross-River States.

\subsection{Sampling}

Crude oils were obtained from Nigeria's Niger Delta region with the assistance of officials from the department of petroleum resources (DPR) and used for the study. The crude oils (one litre each) were collected from Rivers State and Delta State and labelled samples A and F respectively. Mixtures of samples $A$ and $F$ were made at different compositions to give sample B 4:1, sample C 3:2, sample D 2:3 and sample E 1:4 respectively.

\subsection{Crude Oil Characterization}

The density and API gravity of the crude oil samples were determined using the density meter [18].

\subsection{Fractionation of Crude Oil Samples}

The separation of the crude oil samples into saturates, aromatics, resins and asphaltenes (SARA) fractions was achieved by the column chromatography according to Manilla and Onyema [19]. $50 \mathrm{mg}$ of each crude oil sample was weighed into labelled centrifuge tubes and excess pentane added to precipitate the asphaltenes. The content concentrated and introduced onto the top of a glass chromatographic column $(25 \mathrm{~cm} \times 1 \mathrm{~cm})$ packed with activated silica gel. $n$-Hexane was poured into the packed column to elute the saturates, dichloromethane poured to elute the aromatics and dichloromethane/methanol (1:1) mixture poured to elute the resins. The eluents were collected into pre-weighed vials and the solvents evaporated to dryness under a gentle stream of nitrogen at $40^{\circ} \mathrm{C}$. The weights of saturates, aromatics, resins and asphaltenes were determined and the normalized percent reported.

\subsection{Gas Chromatography Analysis}

Analysis of the aliphatic hydrocarbon was performed with an Agilent 7890B gas chromatography (GC) system fitted with an HP-5 silica capillary column $30 \mathrm{~m} \times 320 \mu \mathrm{m}$ ID and 0.25 $\mu \mathrm{m}$ film thickness and equipped with a flame ionization detector (FID). One microlitre $(1 \mu \mathrm{L})$ of the saturate fraction was injected into the GC capillary column with the aid of a G4513A automatic liquid sampler using a split ratio mode of 100:1. Helium was used as the carrier gas. Oven temperature was programmed from 40 to $315^{\circ} \mathrm{C}$ at $5^{\circ} \mathrm{C} / \mathrm{min}$ with a $5 \mathrm{~min}$ hold at $40^{\circ} \mathrm{C}$ and $30 \mathrm{~min}$ hold at $315^{\circ} \mathrm{C}$. Peak identification was by their relative retention times in comparison with internal standard and quantification by area integration of each identified peak. These were processed by Chemstation OPEN LAB CDS software.

\section{Results and Discussion}

\subsection{Bulk Properties}

The bulk properties of crude oils are useful for initial screening of the quality and class of chemical compounds present in the oil. The result of the bulk properties determined for crude oil samples A, F and their mixtures, samples B, C, D, and $\mathrm{E}$ are presented in Table 1.

Table 1. Bulk geochemical properties of the Niger Delta crude oil samples and their mixtures.

\begin{tabular}{|c|c|c|c|c|c|c|}
\hline \multirow{2}{*}{ Bulk properties } & \multicolumn{6}{|c|}{ Samples } \\
\hline & $\mathbf{A}$ & B & $\mathbf{C}$ & D & $\mathbf{E}$ & $\mathbf{F}$ \\
\hline Density (mg/l) & 0.829 & 0.834 & 0.843 & 0.844 & 0.858 & 0.865 \\
\hline API Gravity $\left(^{\circ}\right)$ & 39.19 & 38.16 & 37.32 & 36.15 & 33.42 & 32.08 \\
\hline Saturates (\%) & 71.10 & 70.57 & 70.60 & 70.25 & 71.10 & 68.00 \\
\hline Aromatics $(\%)$ & 25.95 & 25.90 & 26.00 & 25.89 & 26.06 & 24.00 \\
\hline Resin (\%) & 2.75 & 3.40 & 3.23 & 3.62 & 2.61 & 7.62 \\
\hline Alsphaltene (\%) & 0.18 & 0.11 & 0.15 & 0.17 & 0.18 & 0.32 \\
\hline
\end{tabular}

The densities of the crude oil samples range from 0.829 $\mathrm{mg} / \mathrm{l}$, for sample A to $0.865 \mathrm{mg} / 1$ for sample $\mathrm{F}$ (table 1). Crude oils samples $\mathrm{A}$ and $\mathrm{F}$ were mixed at different compositions of $4: 1,3: 2,2: 3$ and $1: 4$ to give samples $\mathrm{B}, \mathrm{C}, \mathrm{D}$, and $\mathrm{E}$ respectively. From table 1, it was observed that the densities of the crude oil samples increased with increase in the composition of oil sample F. API gravity describes the class of the chemical compounds in crude oils, i.e. light or heavy, 
saturated etc. The API gravities of the samples range from $32.08^{\circ}$ to $39.19^{\circ}$ (table 1). Samples A, B, C, and D have high API gravities $\left(>35^{\circ}\right)$ which classify them as light crude oils, while samples $\mathrm{E}$ and $\mathrm{F}$ are classified as medium crude oils. Table 1 showed that the API gravities of the crude oil samples decreased with increase in the composition of oil sample $\mathrm{F}$.

The SARA compositions of the crude oil samples are presented in Table 1. During thermal maturation of crude oils, the high molecular weight compounds are cracked leading to an increase in hydrogen-rich low molecular weight hydrocarbons and saturates [20]. Saturates were the most abundant fraction in all the samples with composition from 68.00 to $71.10 \%$, while the asphaltenes were the least abundant with composition from 0.11 to $0.32 \%$ (table 1 ). The saturate hydrocarbons were significantly more than the other compound classes and indicate all the oil samples were highly matured. This result indicates that the characteristic high-level maturity of the Niger Delta crude oils, sample A and F, was preserved in their mixtures, samples B, C, D, and E.

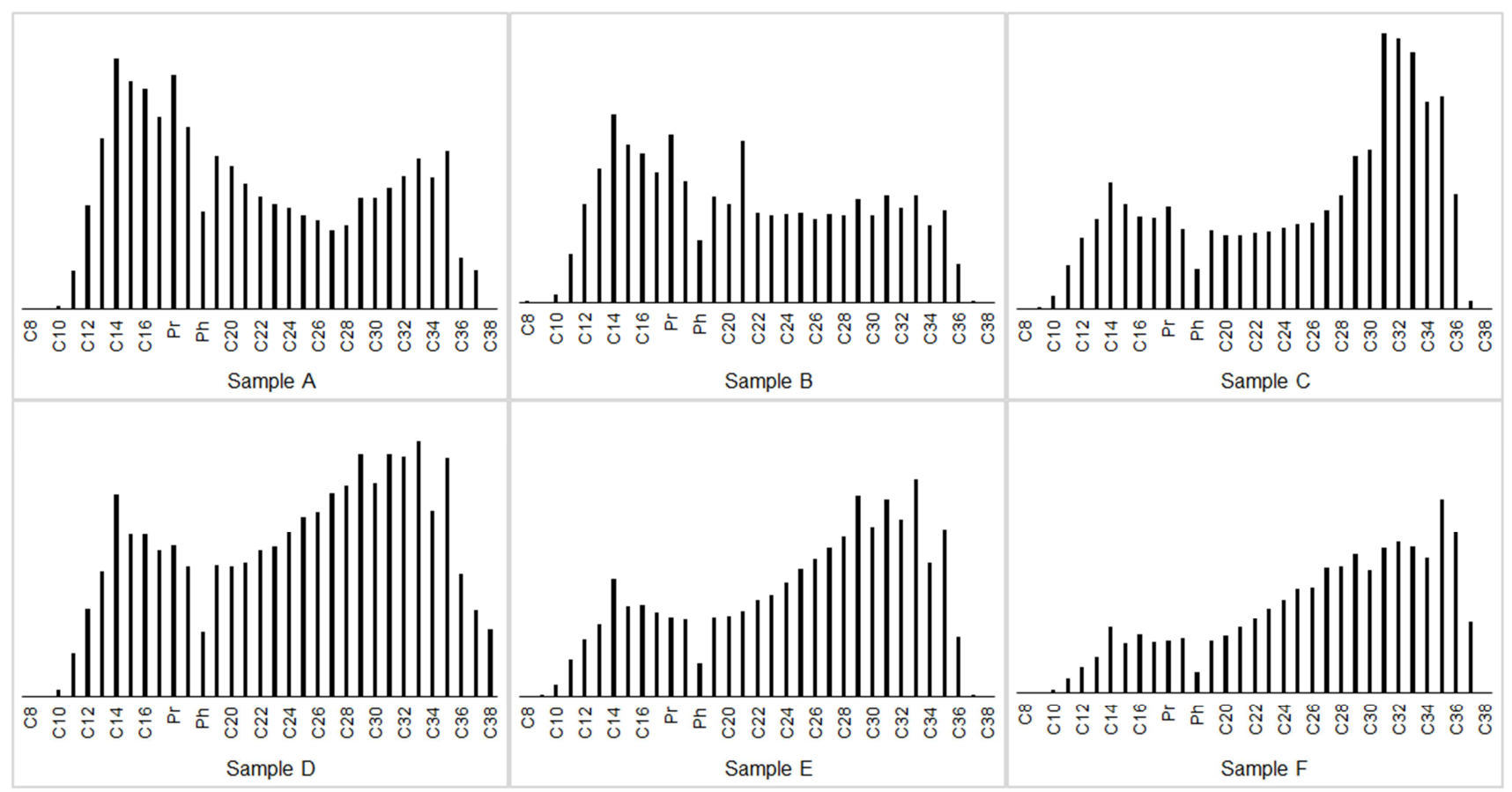

Figure 1. GC-FID chromatogram of the studied Niger Delta crude oil samples and their mixtures showing the distributions of n-alkane and isoprenoids.

\subsection{Distribution of n-Alkanes}

$n$-Alkanes were identified by GC analysis of the saturate fractions which were well resolved. The identified $n$-alkanes range from $n \mathrm{C}_{8}$ to $n \mathrm{C}_{38}$ (figure 1). GC fingerprints of $n$-alkanes characterized by the dominance of short carbon chain $\left(n \mathrm{C}_{13}\right.$ $n \mathrm{C}_{20}$ ) reflect crude oils derived from marine organism sources, while the dominance of the long carbon chain $\left(n \mathrm{C}_{25}-n \mathrm{C}_{35}\right)$ are associated with terrestrial higher plant wax sources [21]. Distribution of $n$-alkanes in the samples consist of both the short and long carbon chain $n$-alkanes (figure 1). Sample A showed a bimodal distribution of $n$-alkanes with a slight prominence of the short chain with the maximum peak carbon number (Cmax) of $n \mathrm{C}_{14}$, while sample $\mathrm{F}$ showed the prominence of the long chain $n$-alkanes and a (Cmax) of $n \mathrm{C}_{35}$. This result suggests that sample A crude oil from Rivers State, which exhibited a bimodal distribution, was derived from marine source with significant terrestrial input to source and sample F crude oil from Delta State was derived from terrestrial organic source. Sample B showed a bimodal $n$ alkane distribution with a slight prominence of the short chain and $\mathrm{Cmax}$ of $n \mathrm{C}_{14}$, which is similar to sample $\mathrm{A}$ and suggest marine source with significant terrestrial input. The $n$-alkane distribution of samples C, D, and E showed the prominence of the long chain $n$-alkanes. This prominence of the long chain $n$ alkanes, which is similar to sample $\mathrm{F}$, was observed to progressively increase respectively. Cmax for sample $\mathrm{C}$ is $n \mathrm{C}_{31}$, sample $\mathrm{D} n \mathrm{C}_{33}$, and sample $\mathrm{E} n \mathrm{C}_{33}$. These $n$-alkane distributions suggest terrestrial source for samples B, C and D. These results reveal that the $n$-alkane features of the two Niger Delta crude oils, samples A and F, were expressed in their mixtures relative to their compositional mix.

\subsection{Composition of Isoprenoids}

The most common isoprenoids in crude oils are pristane $\left(\mathrm{C}_{19}\right)$ and phytane $\left(\mathrm{C}_{20}\right)$. They are generated from the phytyl $\left(\mathrm{C}_{20}\right)$ side chain of chlorophyll molecule in an oxidizing (oxic) or reducing (anoxic) depositional environment respectively [5]. Pristane (Pr) and phytane $(\mathrm{Ph})$ were identified and well resolved in all the oil samples (figure 1). Common ratios derived from the abundance of these isoprenoids, $\mathrm{Pr} / \mathrm{Ph}$, $\mathrm{Pr} / n \mathrm{C}_{17}$ and $\mathrm{Ph} / n \mathrm{C}_{18}$, are calculated for the samples and presented in Table 2. 
Table 2. Calculated isoprenoid ratios for the studied Niger Delta crude oils and their mixtures.

\begin{tabular}{llll}
\hline Samples & $\mathbf{P r} / \mathbf{P h}$ & $\mathbf{P r} / \boldsymbol{n} \mathbf{C}_{\mathbf{1 7}}$ & $\mathbf{P h} / \boldsymbol{n} \mathbf{C}_{\mathbf{1 8}}$ \\
\hline Sample A & 2.40 & 1.22 & 0.53 \\
Sample B & 2.70 & 1.29 & 0.51 \\
Sample C & 2.54 & 1.12 & 0.51 \\
Sample D & 2.37 & 1.04 & 0.49 \\
Sample E & 2.42 & 0.94 & 0.43 \\
Sample F & 2.44 & 1.03 & 0.39 \\
\hline
\end{tabular}

From table 2, $\mathrm{Pr} / \mathrm{Ph}$ ratios which range from $2.37-2.70$ indicate pristane was dominant over phytane $(\mathrm{Ph})$ in all the oil samples. Ratios of $\mathrm{Pr} / \mathrm{Ph}$ less than 1 indicate anoxic deposition, while ratios above 1 reflect oxic depositional environment [22]. $\mathrm{Pr} / \mathrm{Ph}$ ratios of sample $\mathrm{A}(2.40)$ and sample $\mathrm{F}$ (2.44) indicate the Niger Delta crude oils were generated from source rocks deposited in an oxic environment. The ratios obtained for the mixtures of samples A and F are sample B 2.70, sample C 2.54, sample D 2.37 and sample E 2.42. These ratios are consistent with crude oils generated from source rocks deposited in an oxic environment. From the results, it was observed that diagnostic feature of $\mathrm{Pr} / \mathrm{Ph}$ for the two Niger Delta crude oils, samples A and $\mathrm{F}$, was expressed in their mixtures, but did not show a relationship to their compositional mix. Calculated ratios of $\mathrm{Pr} / n \mathrm{C}_{17}$ and $\mathrm{Ph} / n \mathrm{C}_{18}$ for sample $\mathrm{A}$ is 1.22 and 0.53 while for sample $\mathrm{F}$ is 1.03 and 0.39 respectively (table 2 ). $\mathrm{Pr} / n \mathrm{C}_{17}$ ratios less than 0.5 indicate marine organic matter input and values greater than 0.6 indicate terrestrial higher plant input to source. Ratios of $\mathrm{Ph} / n \mathrm{C}_{18}$ less than or equal to 0.3 are typical of crude oil generated from carbonate source rocks and ratio values greater than 0.3 typify shale source rocks [23]. The $\mathrm{Pr} / n \mathrm{C}_{17}$ and $\mathrm{Ph} / n \mathrm{C}_{18}$ ratios of samples $\mathrm{A}$ and $\mathrm{F}$ suggest the studied Niger Delta crude oils were generated from shale source rocks with terrestrial higher plant input. Samples $\mathrm{B}, \mathrm{C}, \mathrm{D}$ and $\mathrm{E}$ ratio values for $\mathrm{Pr} / n \mathrm{C}_{17}$ are $1.29,1.12,1.04$ and 0.94 , while for $\mathrm{Ph} / n \mathrm{C}_{18}$ are 0.51 , $0.51,0.49$ and 0.43 respectively (table 2 ). These ratios suggest crude oils generated from shale source rocks with terrestrial higher plant input. Samples B, C, D, and E are mixtures of samples $A$ and $F$ at different compositions of 4:1, 3:2, 2:3 and 1:4 respectively. From the results, it was observed that diagnostic features of $\mathrm{Pr} / n \mathrm{C}_{17}$ and $\mathrm{Ph} / n \mathrm{C}_{18}$ ratios for the two Niger Delta crude oils, samples A and F, were preserved in their mixtures and relative to their compositional mix.

\section{Conclusion}

Two Niger Delta crude oils from Rivers and Delta States (samples A and F respectively) and their mixtures at different compositions (samples B, C, D, and E) were geochemically characterized using bulk compositional properties and aliphatic hydrocarbon distributions. API gravities classified samples A, B, C and D as light oils, samples E and F as medium oils. The API gravities were relative to the compositional mix of samples A and F (decreased with increase in the composition of oil sample F). The saturate hydrocarbons were significantly more than the other compound classes (aromatics, resins, and asphaltenes), but did not show a relationship to their compositional mix. The prominence of the long chain nalkanes for samples A, B, C and D which progressively decreased suggest terrestrial organic source, while bimodal distribution with a slight prominence of the short chain $n$ alkanes for samples $\mathrm{E}$ and $\mathrm{F}$ suggest mixed marine and terrestrial organic sources. This revealed the $n$-alkane distribution features were expressed relative to the compositional mix of samples $\mathrm{A}$ and $\mathrm{F}$. $\mathrm{Pr} / \mathrm{Ph}$ ratios for all the samples were consistent with deposition in an oxic environment, but with a nonlinear relationship. $\operatorname{Pr} / n \mathrm{C}_{17}$ and $\mathrm{Ph} / n \mathrm{C}_{18}$ ratios suggest shale source rocks with terrestrial higher plant input, which were expressed relative to the compositional mix of samples A and F.

\section{References}

[1] Eneogwe C. I. and Ekundayo O. (2003) Geochemical Correlation of Crude Oils in the NW Niger Delta, Nigeria. Journal of Petroleum Geology 26, 95-103.

[2] Bray, E. E. and Evans, E. D. (1961) Distribution of n-Paraffins as a Clue to Recognition of Source Beds. Geochimica et Cosmochimica Acta 22, 2-15.

[3] Ali, F. M., Al-Khadrawi, R. M, Perzanowski, H. and Halpern, H. J. (2002) Central Saudi Arabia Crude Oil: A Geochemical Investigation. Petroleum Science and Technology 20, 633-654.

[4] Harb, F. S. D., El-Nady, M. M. and Basta, J. S. (2003) Oil-Oil Correlation for some Oil Fields in the North Western Part of the Western Desert, Egypt. Petroleum Science and Technology 21, 1583-1600.

[5] Eneogwe, C. I. and Ekundayo, O. (2002) Some Uncommon Biomarkers occur in Niger Delta Oils. Nigerian Association of Petroleum Explorationist Bulletin 16, 76-80.

[6] Volk, H., George, S. C., Middleton, H. and Schofield, S. (2005) Geochemical Comparison of Fluid Inclusion and Present-Day Oil Accumulations in the Papuan Foreland - Evidence for Previously Unrecognized Petroleum Source Rocks. Organic Geochemistry 36, 29-51.

[7] Onyema, M. O. and Osuji, L. C. (2015) Gas ChromatographyMass Spectrometry (GC-MS) Compositional Analyses of Aromatic Hydrocarbons in Niger Delta Crude Oils. Petroleum and Coal 57(5), 526-531.

[8] Peters, K. E., Walters, C. C. and Moldowan, J. W. (2005) The Biomarker Guide 2nd ed, Cambridge University Press, Cambridge, UK.

[9] Ashoori, S., Sharifi, M., Masoumi, M. and Salehi, M. M. (2017) The Relationship between SARA Fractions and Crude Oil Stability. Egyptian Journal of Petroleum 26, 209-213.

[10] Hunt J. M. (1996) Petroleum Geochemistry and Geology. 2nd Edition, W. H. Freeman and Company, U.S.A.

[11] Nwadinigwe, C. A., Ezugwu, O. K. and Nwadinigwe, A. O. (2017) Assessment of aromatics to saturate ratios in three Niger Delta crudes. Egyptian Journal of Petroleum 26(3), 787-790.

[12] Peters, K. E. and Moldowan, J. W. (1993) The Biomarker Guide: Interpreting Molecular Fossils in Petroleum and Ancient Sediments Prentice Hall, Englewood Cliffs, New Jersey.

[13] Shungunam, G. (1985) Significance of Coniferous Rain Forests and Related Oils, Gippsland Basin, Australia. American Association Petroleum Geologist Bulletin 69, 1241-1254. 
[14] Kolonic, S. C., Sinninghe Damste, J. S., Bittcher, M. E., Kuypers, M. M. M., Kuhntd, W., Beckmann, B., Scheeder, G. and Wegner, T. (2002) Geochemical Characterization of Cenomanian/Turonian Black Shales from the Tarfaya Basins (SW Morocco): Relationship between Paleoenvironmental Conditions and Early Sulphurization of Sedimentary Organic Matter. Journal of Petroleum Geology 25, 325-350.

[15] Oyekunle, L. O. and Famakin, O. A. (2004) Studies of Nigerian Crudes I. Characterization of Crude Oil Mixtures. Petroleum Science and Technology 22, 665-675.

[16] Doust, H. (1990) Petroleum geology of the Niger Delta. London Geochemical Society Special Publications 50, 365.

[17] Tuttle LWM, Charpentier RR and Brownfield EM. Chapter A. Tertiary Niger Delta (Akata-Agbada) petroleum system (No. 719201) Niger Delta Province, Nigeria, Cameroon, and Equatorial Guinea, Africa. U.S. Geological Survey, World Energy Project Open-File Report 1999: 99-50-H.

[18] ASTM Standards 1999. Annual handbook of Standard test method for Density and Relative Density of Liquids by Digital Density Meter, Part 05.03, D4052-96.
[19] Manilla, P. N. and Onyema, O. M. (2008) Correlation of Some Crude Oils using Low Molecular Weight Geochemical Markers: A Case Study of the Niger Delta. Journal of Chemical Society of Nigeria 33, 225-234.

[20] Tissot B. P. and Welte D. H. (1984) Petroleum Formation and Occurrence, A New Approach to Oil and Gas Exploration. Spinger-Verlag, Berlin.

[21] Zhu, C., Pan, J. M. and Lu, B. (2005) Compositional feature of n-alkanes in modern sediments from the Changjing Estuary and adjacent area and its implication to transport and distribution of organic carbon. Acta Oceanologica Sinica 27(4), 59-67.

[22] ten Haven, H. L., Rullkötter, J., De Leeuw, J. W. and Sinninghe Damste, J. S. (1988) $\mathrm{Pr} / \mathrm{Ph}$ Ratio as Environmental Indicator: Reply. Nature 333, 604.

[23] Younes, M. A. (2001) Application of Biomarkers and Stable Carbon Isotopes to Access the Depositional Environment of Source Rocks and the Maturation of Oils, East Zeit Field, Southern Gulf of Suez Egypt. Petroleum Science and Technology.19, 1039-1081. 